Note

\title{
Carburization of Titanium Oxide by Means of Plasma Jet
}

\author{
Osamu MAtsumoto* and Michio SaIto*
}

The metal carbides such as $\mathrm{VC}^{1)}, \mathrm{ZrC}^{2), 3)}$ and $\mathrm{NbC}^{4)}$ were formed by carburization of respective oxides with carbon by heating with plasma jets. However, the formation of stoichiometric $\mathrm{TiC}$ by carburization of $\mathrm{TiO}_{2}$ is difficult, because $\mathrm{TiO}$ and $\mathrm{TiC}$ form solid solution ( $\delta$-phase) of fcc crystal structure. Therefore, TiC has been formed so far in the solid state in vacuum or in an inert atmosphere ${ }^{5), 6)}$. In the present experiment, the carburization of $\mathrm{TiO}_{2}$ with graphite by heating with argon plasma jet was attempted and some properties of the product were investigated.

$\mathrm{TiO}_{2}$ (rutile type powder supplied by Toho Titanium Mfg. Co. and having a purity of $99.5 \%$ up) and graphite powder (spectroscopic grade, Tokai Electrode Co.) were mixed in a desired ratio. About $1 \mathrm{~g}$ of mixture was pressed into a tablet of $15 \mathrm{~mm}$ in diameter and $3 \mathrm{~mm}$ thick. The method of carburization of $\mathrm{TiO}_{2}$ with graphite was the same as mentioned previously ${ }^{2), 3)}$. The surface temperature of $\mathrm{TiO}_{2}$-graphite mixture tablet under the argon plasma jet was higher than the melting point of $\mathrm{TiO}_{2}$ at the current of $60 \mathrm{~A}$ and increased with increasing current. The temperature reached the melting point of $\mathrm{TiC}\left(3130^{\circ} \mathrm{C}\right)$ at the current of $140 \mathrm{~A}$.

After the plasma jet bombardment, a metallic cakes of varying color from gold to blackish, were obtained on the graphite hearth anode. The products were found to be the mixture of $\mathrm{TiC}, \mathrm{TiC}_{\mathrm{x}} \mathrm{O}_{\mathrm{y}}$ ( $\delta$-phase), $\mathrm{TiO}$ and graphite by $\mathrm{X}$-ray diffraction. Chemical analyses showed that the carbon content in the cake varied considerably with the experimental condition. $\mathrm{CO}$ was the only detectable gaseous product by gas chromatography.

The chemical analyses and X-ray diffraction data of products formed in various molar mixing ratio of graphite to $\mathrm{TiO}_{2}\left(\mathrm{C} / \mathrm{TiO}_{2}\right)$ are listed in Table 1. The combined carbon content increased with increasing $\mathrm{C} / \mathrm{TiO}_{2}$ up to $\mathrm{C} / \mathrm{TiO}_{2}=3$. The combined carbon content at $\mathrm{C} / \mathrm{TiO}_{2}=3$ corresponded to that of stoichiometric TiC. The lattice parameter of the product ob-

\footnotetext{
- Department of Chemistry, College of Science and Engineering, Aoyama Gakuin University (6-16-1), Chitosedai, Setagaya-ku, Tokyo)
}

Table 1 Chemical analyses and X-ray diffraction data of the products under various $\mathrm{C} / \mathrm{TiO}_{2}$

\begin{tabular}{c|c|c|c|c|c}
$\mathrm{C} / \mathrm{TiO}_{2}$ & $\begin{array}{c}\mathrm{Ti} \\
\text { content } \\
\text { (wt. \%) }\end{array}$ & $\begin{array}{c}\text { Free } \mathrm{C} \\
\text { content } \\
\text { (wt. \%) }\end{array}$ & $\begin{array}{c}\text { Combined } \\
\mathrm{C} \text { content } \\
\text { (wt. \%) }\end{array}$ & $\begin{array}{l}\text { Identified } \\
\text { species by } \\
\text { X-ray } \\
\text { diffraction }\end{array}$ & $\begin{array}{c}a_{\mathrm{o}} \text { of fcc } \\
\text { phase } \\
(\AA)\end{array}$ \\
\hline 1.0 & 70.7 & 0.27 & 0.33 & $\mathrm{TiO}$ & - \\
2.0 & 78.7 & 0.43 & 6.90 & $\mathrm{TiC}_{\mathbf{x}} \mathrm{O}_{\mathrm{y}}$ & 4.280 \\
2.5 & 78.8 & 0.38 & 12.40 & $\mathrm{TiC}_{\mathrm{x}} \mathrm{O}_{\mathrm{y}}$ & 4.316 \\
3.0 & 79.7 & 1.53 & 19.91 & $\mathrm{TiC}$ & 4.325 \\
3.5 & 72.7 & 8.43 & 19.06 & $\mathrm{TiC}, \mathrm{C}$ & 4.325 \\
4.0 & 68.2 & 14.54 & 17.18 & $\mathrm{TiC}, \mathrm{C}$ & 4.325 \\
\hline
\end{tabular}

Reaction conditions : $150 \mathrm{~A}$, flow rate of $\mathrm{Ar} 4$ liters/ $\min , 3 \mathrm{~min}$

tained at $\mathrm{C} / \mathrm{TiO}_{2}=3$ was $4.325 \AA$. It was confirmed to be stoichiometric $\mathrm{TiC}$.

The infuence of the current on the reaction was investigated by heating the tablet of $\mathrm{C} / \mathrm{TiO}_{2}=3$ for 3 min under various current. When the current exceeded $130 \mathrm{~A}$ (about $3000^{\circ} \mathrm{C}$ ), the combined carbon content increased remarkably and the product was stoichiometric TiC. Therefore, it is considered that the reaction in the liquid state proceeds more rapidly than that in the solid state.

The influence of the reaction time on the carburization at $\mathrm{C} / \mathrm{TiO}_{2}=3$ and at $150 \mathrm{~A}$ was investigated. The combined carbon content increased with increasing reaction time up to $2 \mathrm{~min}$ and then it remained constant. When the reaction time exceeded $2 \mathrm{~min}$, the stoichiometric $\mathrm{TiC}$ was formed and the deoxidation was almost complete.

From the results obtained above, the optimum mixing molar ratio of graphite to $\mathrm{TiO}_{2}$ was 3 and the overall reaction may be as $\mathrm{TiO}_{2}+3 \mathrm{C}=\mathrm{TiC}+2 \mathrm{CO}$. In this case, the reaction proceeded quickly in the liquid state.

The relation between the lattice parameter of fcc phase in the product and the combined carbon content is shown in Fig. 1. The products except stoichiometric $\mathrm{TiC}$ were solid solutions of $\mathrm{TiO}$ and $\mathrm{TiC}$ ( $\delta$-phase). The lattice parameter increased with increasing com- 


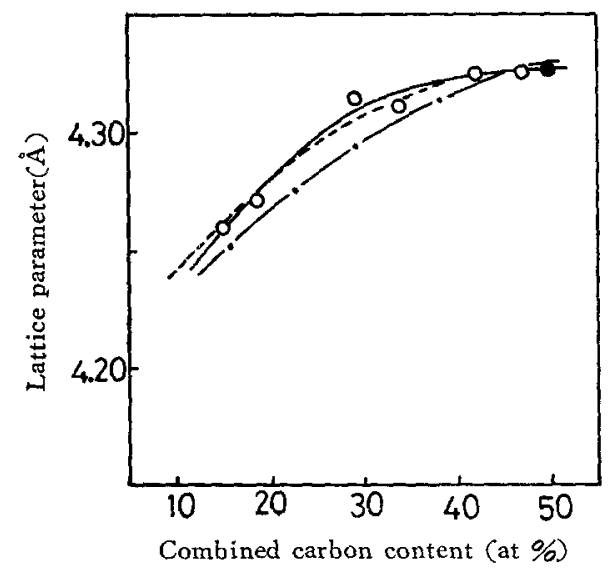

Fig. 1 Lattice parameter vs. combined carbon content bined carbon content up to 40 at. $\%$. Although small amounts of oxygen was included in the lattice, the lattice parameter was nearly equal to that of stoichiometric TiC. The measured density of stoichiometric $\mathrm{TiC}$ by the water displacement method was $4.90 \mathrm{~g} / \mathrm{cm}^{3}$. The X-ray density of stoichiometric TiC was $4.91 \mathrm{~g} / \mathrm{cm}^{3}$.

(Received March 22, 1973)

\section{References :}

1) K. Hanusch, H. Winterhager, Metall 10, 1061 (1970).

2) O. Matsumoto, T. Miyazaki, This Jous nal 39, 388 (1971).

3) O. Matsumoto, T. Miyazaki, High Temp. Sci. 5, 40 (1973).

4) K. Akashi, R. Ishizuka, I. Egami, J. Min. Met. Inst. Japan B8, 885 (1972), (in Japanese).

5) H. Nishimura, K. Kimura, J. Japan Inst. Metals 20, 528 (1959), (in Japanese).

6) T. Kubo, K. Kanriki, Kogyo Kagaku Zasshi 63, 64 (1960), (in Japanese).
$-\mathrm{O}-\mathrm{T}$ : This work, $\mathrm{TiC}, \mathrm{O}: \mathrm{TiC}_{\mathrm{x}} \mathrm{O}_{\mathrm{y}}$ : Nishimura et al.
: Kubo et al.

弇本「電気华学測定洼」m

電気化学協会編 B 5 判 本文 180 ベージ 頒布価格 1,500 円（蒵料別 200 円）

申込先・テ100 東京都千代田区有楽町 1-11 新有楽町ビル 電気化学協会 (電話 03 (214) 6001)

本誌揭載の講義シリーズ “電気化学測定法”は完結しました。

電気化学湘定法は, 化学反応機構の解明，生体機能の計測など基礎的研究の面から，各種のブロセス計測にみられ

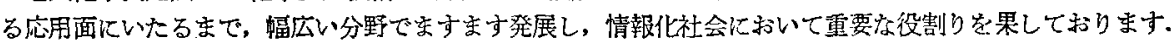

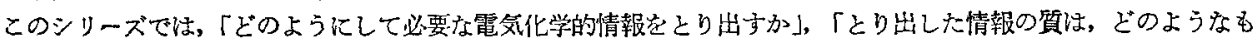
のであるか」または「複雑系加らの情報のとり出しちならびにその処理」についてまとめられました。

このたび，本講義シリーズを拔粋，集録して，合本「電気化学測定法」艺刊行しました，皆さまの重ねてのご要読 を持ちします。

I. 基礎理論および測定回路

電気化学測定法についての対話

..内

電気化学測定法の考え方

玉虫伶太

增子 昇

電極電位の測定

春山志郎

電流電位他線について

高村 化地・藤社一

電位走查法 (1)，(2)，(3)

ステップ大力信号に対する交流測定 (1), (2)

上木克己・高橋正雄

電気化学に括讨る交流測定 (1),(2) 春山志郎

ポーラログラフ装置竹盛欣男・松田 清

定電流バルス実験法神崎 愷・青柳 茂

演算堛罍器のえらび方, 使い方 (1), (2)

仁來克己

II. 応用

日程文男
容

溶融塩系への纫用 (1),(2), (3)

渡辺信淳・金谷泰宏

一瀨光之尉

平茾竹次・伊藤 要

電池電極反忍の電気化学的測定と乥の解析

竹原善一郎

腐食研究人の态用 (1),(2) 日根支男・保田昌樹 鉿木紹夫 ·小宮健作・北村義治 固体電解犋研究人の応用 (1)，(2)

高橋武彦・山本 治 滈橋武应・岩原弘育・鈴木 豊 非水溶媒䒺人の応用藤永太一郎・佐藤昌憲 電食測定への空用山田保・伍藤 要 「電位測定の諸問題渡辺 昌・西讯和夫 生物化学への応用鈴木周一・相沢益男 